\title{
Chinese and Japanese Progressive Aspectual Markers in Comparison with English
}

\author{
Wenxiao Zhao \\ School of Foreign Languages \\ University of Jinan \\ Jinan, China
}

\author{
Yiji Gao \\ School of Foreign Languages \\ University of Jinan \\ Jinan, China
}

\begin{abstract}
The present study is devoted to interpreting Chinese and Japanese progressive markers, their meanings and usage in comparison with English, while reasoning ungrammaticality from the perspective of Aktionsart.
\end{abstract}

Keywords-Chinese progressive markers; Japanese progressive markers; aktionsart; telic; multilingual comparison

\section{INTRODUCTION}

Talking about universal grammar, the term aspect, according to Quirk, et al. (1985:90), refers to the manner in which the verb action is regarded or experienced. The choice of aspect is a comment on or a particular view of the action. Lyons (1977:707) mainly introduced the term aspectual feature which consists of speakers' conception of the constituency of an actual situation referred to by the corresponding semantic properties of verbs. Smith (1983) first discerned grammatical aspects, morphologically understood as the use of auxiliary structure be+ verb + -ing in English from lexical aspects.

When we refer to the lexical aspect (or AKTIONSART), we need to mention firstly Vendler (1967:97) who made the classical classifications as it is showed in "Table I".

TABLE I. V VENDLER’s ClassificATION OF LEXICAL ASPECT (1967)

\begin{tabular}{|c|c|}
\hline Classifications & Examples \\
\hline Statives & desire, want, love, hate, know, believe. \\
\hline Activities & run, walk, swim, \\
\hline Accomplishments & run a mile, draw a circle, \\
\hline Achievements & recognize, find, stop, start \\
\hline
\end{tabular}

Vendler's classification was focused on whether it has a natural ending. Later scholars dealing with the categorization of aspectual situations often refer to the socalled Vendler's categorization. Later in Smith's (1997:28) articles, a new type named semelfactive was added to distinguish it from achievement as showed in "Table II".

TABLE II. A SMITH's ClASSIFICATION OF LEXICAL ASPECT (1997)

\begin{tabular}{|l|l|l|l|l|}
\hline \multicolumn{1}{|c|}{ Situations } & $\begin{array}{c}\text { Telic (+) } \\
\text { Atelic (-) }\end{array}$ & $\begin{array}{c}\text { Dynamic(+) } \\
\text { Static (-) }\end{array}$ & $\begin{array}{c}\text { Durative(+) } \\
\text { Punctual (-) }\end{array}$ & \multicolumn{1}{c|}{ Example } \\
\hline Stative & - & - & + & She hated ice cream. \\
\hline Activity & - & + & + & Your cat watched those birds \\
\hline Accomplishment & + & + & + & Her boss learned Chinese. \\
\hline Achievement & + & + & - & The cease-fire began at noon yesterday. \\
\hline Semelfactive & + & + & - & The gate banged. \\
\hline
\end{tabular}

According to Smith, telic refers to those processes which are deemed as having a natural completion, e.g.: Harry was building a raft. Static verbs, like be, know and love, allow the speaker to view a situation as a steady state with no internal phases or changes. Durative is applied to verbs which describe a situation or a process which lasts for a period of time, while punctual describes an event that seems so instantaneous that involves virtually no time, e.g.: John coughed.

The progressive aspect, conventionally defined as a grammatical means of describing 'a happening in progress at a given time' (Quirk et al., 1985), is conceived of as a subset of the imperfective aspect. In regards to cognitive linguistics, Langacker (1990:91) puts forward that the progressive is an imperfectivizing construction, that is to say, for example in English, be + Verb + -ing is an imperfectivizer. On this point of view, he equates the perfective/imperfective contrast with the active/stative contrast (Langacker, 1990: 86). Therefore the structure be + Verb + -ing can be understood as a stativizer as we have mentioned in the first part of this research paper. Here we can observe that according to Langacker, the meaning of the essence of the progressive is to represent an active or dynamic action as a state; that is to say, the predicate in the progressive is a state, not an event. Others researchers such as Vlach (1981) held the same idea that progressive should be seen as a stativizer, which serves to transform a non-stative sentence into a stative one.

Langacker and Vlach's point of view about progressive construction be a stativizer seems contradictory to the dynamic nature of the progressive, in fact, they just describe the progressive construction from different angles. Langacker's reflection is derived from the grammatical aspect perspective (viewpoint aspect), while others from the 
lexical aspect (situation aspect) perspective. In this case, on the basis of Langacker, the input lexical should have the property of an activity. If other lexical aspects were put into the progressive construction, as we have mentioned above, extra pragmatic meanings would be added.

\section{CHINESE AND JAPANESE VERBS}

In China, J. Tai (1984) was the first Chinese researcher who introduced Vendler's classification of lexical aspect into Chinese studies. Stative verbs in Chinese can be interpreted as two subcategories. Some of them can be used as linking verbs to express syntactic relations such as shi 'be', you 'have', zai 'be in'; others are used to indicate mental states such as xihuan 'love', dong 'know', renwei 'think'. Activity verbs contain those who have natural final endpoints like dengdai 'wait' and fendou 'fight' or don't have such endpoints like paobu 'run' and dushu 'read'. Chinese accomplishments verbs can be manifested themselves in two patterns: verb+ object like du pian xiaoshuo 'read a novel' and verb +complement of result like zhanggao 'grow up'. Achievements and semelfactives verbs are quite similar to the Smith's division of English verbs.

Also based on the Smith's model of pair features, Japanese researcher Kindaichi (1976) divided Japanese verbs into five categories. The author intended to interpret two types of activity: the continuative and the instantaneous. The former kind is featured by durative, dynamic which coincides with the 'classical' activity and accomplishment aspects in Vendler and Smith's category while the instantaneous aspect in Japanese can be considered as achievement according to the classical one. This categorization without doubts leads problems in the presentations of progressive markers as in "Table III".

\section{TABLE III. CLASSIFICATION OF LEXICAL ASPECT}

\begin{tabular}{|c|l|}
\hline Stative & $\begin{array}{l}\text { aru (ある) 'have', dekiru (できる)'can do', mieru (見 } \\
\text { える)'be visible' }\end{array}$ \\
\hline Continuative & $\begin{array}{l}\text { Yomu (読む)'read', kaku (書く)'write', narau (習 } \\
\text { う) 'learn' }\end{array}$ \\
\hline Instantaneous & $\begin{array}{l}\text { Sinu (死ぬ)'die', kieru (消える)'turn off', kimaru(決 } \\
\text { まる)'decide', }\end{array}$ \\
\hline Type 4 & $\begin{array}{l}\text { Sobieru (筰える)'emerge', sugureru (優れる)'be } \\
\text { outstanding' }\end{array}$ \\
\hline
\end{tabular}

\section{COMPARISONS AND ANALYSIS}

To show Japanese and Chinese examples, we use Liu \& Zhao's (2015:155) four-line framework. The first line shows the original Japanese characters in Kanji/Kana formation and Chinese characters in Hanzi formation. The second line gives the pronunciation of each word or phrase. In the third line, the literal translation into English of each word or group has been added. And the last underlined phrase shows a grammatical English sentence which is faithful to the literal meaning of the translation.

\section{A. Stative Verbs}

Stative verbs are the most problematic category when we compare the examples of different languages. First of all, it is not common that stative verbs combine with the progressive aspect. In English, a large set of English stative verbs do not normally accept progressive markers, including psychological and cognitive verbs such as love, believe, know, etc. The incompatibility seems to be that since progressive aspect presents a situation as ongoing, it requires that situation have successive phases which is inherently dynamic, whereas the stative verbs indicate only homogenous situations. This is why the sentence such as "He is loving her deeply." is completely unacceptable.

In regards to the statives in Chinese progressive construction, Smith (1997) pointed out that the Chinese aspectual marker -zhe can be added to stage-level stative sentences to denote transitory properties, while their English counterparts, if progressivized, sound unnatural, as in "Table IV and "Table V".

TABLE IV. Chinese Stative Verb: Ai 'Love'

\begin{tabular}{|l|l|l|l|l|}
\hline \multicolumn{1}{|c|}{ 他 } & \multicolumn{1}{|c|}{ 深 } & \multicolumn{1}{c|}{ 爱 } & \multicolumn{1}{c|}{ 着 } & 她 \\
\hline $\mathrm{Ta}$ & Shen & $\mathrm{Ai}$ & Zhe & ta \\
\hline $\mathrm{He}$ & Deep & Love & Progressive aspectual Marker & her \\
\hline $\begin{array}{l}\text { He loves her deeply. } \\
\text { *He is loving her deeply. }\end{array}$ \\
\hline
\end{tabular}

Table V. Chinese Stative Verb: Cunzai 'Exist'

\begin{tabular}{|c|c|c|c|c|}
\hline 这家 & 公司 & 存在 & 着 & 问题 \\
\hline Zhejia & Gongsi & Cunzai & Zhe & Wenti \\
\hline This & Company & exist & $\begin{array}{l}\text { Progressive } \\
\text { aspectual marker }\end{array}$ & Problem \\
\hline \multicolumn{5}{|c|}{$\begin{array}{l}\text { There exist problems in this company. } \\
\text { *There are existing problems in this company. } \\
\text { This company has problems. } \\
\text { *This company is having problems. }\end{array}$} \\
\hline
\end{tabular}

There is a very limited number of stative verbs in Japanese, according to Kindaichi (1976:10), incompatible with the progressive markers -teiru, such as the existential verb aru 'exist' in the example of "Table VI". Apart from these limited verbs, the majority of stative verbs can be added the progressive marker as it is showed in the example of "Table VII" though they cannot be translated parallelly in English.

TABLE VI. JaPANESE Stative Verb: AU 'Love'

\begin{tabular}{|l|l|l|l|l|}
\hline \multicolumn{1}{|c|}{ かれは } & \multicolumn{1}{|c|}{ 彼女を } & \multicolumn{1}{c|}{ 深く } & あいし & \multicolumn{1}{c|}{ ている } \\
\hline Kare-wa & Kanojyo-wo & Fukaku & aishi & Teiru \\
\hline $\begin{array}{l}\text { He -theme } \\
\text { marker }\end{array}$ & $\begin{array}{l}\text { She -object } \\
\text { marker }\end{array}$ & Deeply & Love & $\begin{array}{l}\text { Progressive } \\
\text { aspectual marker }\end{array}$ \\
\hline $\begin{array}{l}\text { He loves her deeply. } \\
\text { *He is loving her deeply. }\end{array}$
\end{tabular}

TABLE VII. JAPANESE STATIVE VERB: ARU 'EXIST'

\begin{tabular}{|c|c|c|c|c|}
\hline *この & 会社に & 問題が & あっ & ている \\
\hline *Kono & Kaisya-ni & Mondai-ga & A-(t) & Teiru \\
\hline This & $\begin{array}{l}\text { Company - } \\
\text { locative marker }\end{array}$ & $\begin{array}{l}\text { Problem }- \\
\text { subject marker }\end{array}$ & Exist & $\begin{array}{l}\text { Progressive } \\
\text { aspectual } \\
\text { marker }\end{array}$ \\
\hline \multicolumn{5}{|c|}{$\begin{array}{l}\text { There exist problems in this company. } \\
\text { *There are existing problems in this company. } \\
\text { This company has problems. } \\
\text { *This company is having problems. }\end{array}$} \\
\hline
\end{tabular}


Though the marker -zhe in Chinese co-occurs with the stage-level stative, that is not to say, any statives can combine with the progressive marker. For those with the individual-level, as the linking verbs: shi 'be', shuyu 'belong to', etc, and others to express the emotional activity, as $p a$ 'fear', yuanyi 'would like', mingbai 'understand' cannot combine with the progressive marker either as it is illustrated in the examples of "Table VIII" and "Table IX".

TABLE VIII. Chinese Stative Verb: Shi 'BE’

\begin{tabular}{|l|l|l|l|}
\hline \multicolumn{1}{|c|}{$*$ 他 } & \multicolumn{1}{|c|}{ 是 } & \multicolumn{1}{c|}{ 着 } & \multicolumn{1}{c|}{ 老师 } \\
\hline$* \mathrm{Ta}$ & $\mathrm{Shi}$ & Zhe & Laoshi \\
\hline $\mathrm{He}$ & $\mathrm{Be}$ & Progressive aspectual marker & Teacher \\
\hline \multicolumn{4}{|l}{ He has been a teacher. } \\
\hline
\end{tabular}

TABLE IX. Chinese Stative Verb: MingBai 'Understand'

\begin{tabular}{|c|c|c|c|c|}
\hline *他 & 明白 & 着 & 这个 & 事情 \\
\hline$* \mathrm{Ta}$ & Mingbai & Zhe & Zhege & Shiqing \\
\hline $\mathrm{He}$ & understand & Progressive aspectual marker & This & Thing \\
\hline
\end{tabular}

TABLE X. JAPANESE StATive Verb: DA 'BE'

\begin{tabular}{|l|l|l|l|}
\hline \multicolumn{1}{|c|}{ かれわ } & \multicolumn{1}{|c|}{ 先生 } & \multicolumn{1}{c|}{ だっ } & \multicolumn{1}{c|}{ ている } \\
\hline Kare-wa & Sensei & Da -(t) & Teiru \\
\hline He -theme marker & Teacher & be & Progressive aspectual marker \\
\hline
\end{tabular}

Different from the existential verb aru 'exist', the copulative verb $d a$ 'be' is commonly employed with the progressive markers. Compared to the unnatural case in Chinese, in the Japanese example in "Table X", the sentence not only manifests a grammatical acceptance but also a pragmatic meaning that indicates a large duration of being a teacher, including some habitual aspectual meanings.

In the last Japanese example in "Table XI", the pragmatic meaning is obvious. When someone repeats something that you have known well and have been experienced at, the sentence is used for insisting that you have already understood and to stop him repeating that.

TABLE XI. JAPANESE STATIVE VeRB: WAKARU 'UNDERSTAND'

\begin{tabular}{|l|l|l|l|l|}
\hline \multicolumn{1}{|c|}{ 私は } & \multicolumn{1}{c|}{ そんな } & \multicolumn{1}{c|}{ ことを } & \multicolumn{1}{c|}{ 分っ } & \multicolumn{1}{c|}{ ている } \\
\hline Watashi-wa & Sonna & Koto-wo & Waka-(t) & Teiru \\
\hline $\begin{array}{l}\text { He -theme } \\
\text { marker }\end{array}$ & such & $\begin{array}{l}\text { Thing - } \\
\text { object } \\
\text { marker }\end{array}$ & Understand & $\begin{array}{l}\text { Progressive } \\
\text { aspectual } \\
\text { marker }\end{array}$ \\
\hline
\end{tabular}

\section{Activity Verbs}

As for the Chinese and Japanese activity verbs, the temporal properties of the activities are congruent with the 'action in progressive' essence of the progressive construction as in the examples in "Table XII" and "Table XIII".
TABLE XII. Chinese Activity Verb: Zou 'WALK’

\begin{tabular}{|l|l|l|}
\hline \multicolumn{1}{|c|}{ 他 } & \multicolumn{1}{c|}{ 走 } & \multicolumn{1}{c|}{ 着 } \\
\hline $\mathrm{Ta}$ & Zou & Zhe \\
\hline $\mathrm{He}$ & walk & Progressive aspectual marker \\
\hline $\mathrm{He}$ is walking.
\end{tabular}

TABLE XIII. JAPANESE ACTIVITY Verb: ARUKU 'WALK'

\begin{tabular}{|l|l|l|}
\hline \multicolumn{1}{|c|}{ かれが } & \multicolumn{1}{|c|}{ 歩い } & \multicolumn{1}{c|}{ ている } \\
\hline Kare-ga & Arui(t) & Teiru \\
\hline He -subject marker & Walk & Progressive aspectual marker \\
\hline He is walking.
\end{tabular}

The two examples above express the meaning of the ongoing of the state of walking where the progressive construction as a stativizer has successfully converted the activities into the states. Here we can observe that the progressives, whether in Chinese or in Japanese, can prototypically coincide with activities. There exist similarities in the use of progressive markers in these two languages and in English when they are added to the activity verbs due to the prototypical feature of such verbs, that is to say, they can be stativized easily by the progressive markers.

\section{Accomplishments Verbs}

Compared with the activity verbs, we can see that the accomplishment can also exist compatibly with progressive construction in Chinese. As we know, this accomplishment phrase xie yipian wenzhang 'write an article' is derived directly from the activity verb xie 'write' with an object added. The meaning of accomplishments occurs in the progressive construction is to denote a state which holds during the time that a particular activity goes on. Therefore the example of "Table XIV" is to indicate that the preparatory activity (write) is going on at some point, whether or not the preparatory activity led to its logical goal (a finished article) has been neglected.

TABLE XIV. CHINESE ACCOMPLISHMENTS VerB: XIE-WENZHANG 'WRITE AN ARTICLE'

\begin{tabular}{|l|l|l|l|}
\hline \multicolumn{1}{|c|}{ 他 } & \multicolumn{1}{|c|}{ 正在 } & \multicolumn{1}{c|}{ 写 } & \multicolumn{1}{c|}{ 文章 } \\
\hline $\mathrm{Ta}$ & Zhengzai & Xie & Wenzhang \\
\hline $\mathrm{He}$ & Progressive aspectual marker & Write & Article \\
\hline \multicolumn{4}{|l}{$\mathrm{He}$ is writing an article. }
\end{tabular}

However, in spite of the grammatical correction of the Japanese example in "Table XV", it leads us two directions to do the interpretation. Normally, as a prototypical progressive marker, -teiru is used for indicating the continuity of the activity as the most common meaning 'he is writing an article'. But when the verb kaku 'write' has been added an object bunsyou 'article' to form an accomplishments verb, the progressive marker -teiru can be considered as a pursuit of the aim of making an accomplishment aspect a real finished or accomplished event. In this sense, we obtain the second interpretation. That is 'the article has been written and finished'. 
TABLE XV. JAPANESE ACCOMPLISHMENT VERB: BUNSYOU-WO KAKU 'WRITE AN ARTICLE'

\begin{tabular}{|c|c|c|c|}
\hline かれが & 文章を & 書い & ている \\
\hline Kare-wa & Bunsyou-wo & Kai & Teiru \\
\hline $\mathrm{He}$ & Article & Write & Progressive aspectual marker \\
\hline
\end{tabular}

\section{Achievements Verbs}

As we know that achievements are different from activities and accomplishments in that they don't involve a process phase that leads to a completion point in the case of an accomplishment, but denote a sudden transition from one stage to another with no duration. Therefore the inherently punctual and instantaneous nature of achievements constitutes not compatible with the durative, incomplete nature of progressive construction.

Normally in English the achievements predication "win the game" seems incompatible with the progressive construction, because it lacks the requisite durability. However, according to Rothstein (2004:37), this English sentence is also highly interpretable, which yield a 'slowmotion' or 'film-strip' reading, and the normally instantaneous event is perceived as being 'stretched' over time.

TABLE XVI. CHINESE ACHIEVEMENTS VERB: YING 'WIN'

\begin{tabular}{|c|l|l|l|l|}
\hline$*$ 他 & \multicolumn{1}{|c|}{ 正 } & \multicolumn{1}{|c|}{ 赢 } & \multicolumn{1}{c|}{ 着 } & \multicolumn{1}{|c|}{ 比赛 } \\
\hline$* \mathrm{Ta}$ & Zheng & Ying & Zhe & Bisai \\
\hline $\mathrm{He}$ & $\begin{array}{l}\text { Progressive aspectual } \\
\text { Marker }\end{array}$ & Win & $\begin{array}{l}\text { Progressive } \\
\text { aspectual marker }\end{array}$ & $\begin{array}{l}\text { The } \\
\text { game }\end{array}$ \\
\hline \multicolumn{4}{|l|}{ He is winning the game. }
\end{tabular}

When we come to the Chinese example in "Table XVI", we tried to form a progressive sentence with the achievements verb ying 'win'. But the outcome of the sentence is conceptually anomalous. It may be due to the fact that the progressive marker zai- and -zhe, which denotes an interval without an endpoint, is incompatible with achievements, and the incompatibility cannot be interpreted as the same 'film-strip' as in English.

In Japanese, due to the strong nature of achievements verb, which focus on the endpoint and takes less importance about the whole process, the continuous aspectual effect of the marker -teiru has lost gradually while the resultative interpretation tends to be more prototypical in this special context. For this reason, compared to the Chinese sentence, it is grammatically acceptable in Japanese the combination of progressive markers and the achievements verbs. But the original 'progressive' meaning gets lost.

TABLE XVII. JAPANESE ACHIEVEMENTS VERB: KATSU 'WIN'

\begin{tabular}{|l|l|l|l|l|}
\hline かれが & $こ の$ & ゲームを & 勝っ & ている \\
\hline Kare-ga & Kono & Geimu-wo & Ka-(t) & Teiru \\
\hline $\begin{array}{l}\text { He -subject } \\
\text { marker }\end{array}$ & This & $\begin{array}{l}\text { Game -object } \\
\text { marker }\end{array}$ & Win & $\begin{array}{l}\text { Progressive } \\
\text { aspectual } \\
\text { marker }\end{array}$ \\
\hline \multicolumn{4}{|l|}{ He won the game } & \\
\hline
\end{tabular}

The study of Kindaichi (1954) reported that Japanese punctual verbs get a "resultative state" interpretation when used in the Verb+ -teiru form. For example shinu 'die' is a typical punctual verb as it is showed in the example of "Table XVII". But in the Chinese example in "Table XVIII", we also failed to give an interpretation to fill the gap of the incompatibility between the progressive marker -zhe and the verb $s i$ 'die'.

TABLE XVIII. ChINeSE ACHIEVEMENTS Verb: Si 'DIE'

\begin{tabular}{|l|l|l|}
\hline \multicolumn{1}{|c|}{$*$ 他 } & \multicolumn{1}{|c|}{ 死 } & \multicolumn{1}{c|}{ 着 } \\
\hline$* \mathrm{Ta}$ & $\mathrm{Si}$ & Zhe \\
\hline $\mathrm{He}$ & Die & Progressive aspectual marker \\
\hline He is dying. \\
He is dead. \\
\hline
\end{tabular}

TABLE XIX. JAPANESE ACHIEVEMENTS VERB: SHINU 'DIE'

\begin{tabular}{|l|l|l|}
\hline \multicolumn{1}{|c|}{ かれが } & \multicolumn{1}{|c|}{ 死ん } & \multicolumn{1}{c|}{ でいる. } \\
\hline kare-wa & Shin & Deiru (voiced form of teiru). \\
\hline He & Die & Progressive aspectual marker \\
\hline He is dying. \\
He is dead.
\end{tabular}

Okuda (1979) criticized the foregoing studies and maintained that there is a general lexical meaning for those verbs which receive a resultative interpretation. The author denominated those verbs "subject-change" verbs, as it has been found that the subjects of those verbs undergo a certain change as a result of the action of those verbs, and when they are employed with Verb-teiru form, they receive a resultative state interpretation. In the example "Table XVII" and "Table XVIII", verbs like katsu 'win' and shinu 'die' all suggest physical changes.

\section{CONCLUSION}

Peoples' cognitive differences and different viewpoint towards time give rise to the differences in different languages. Both Chinese and Japanese emphasize the uses of progressive aspectual markers as one of the highlighted linguistic feature in oriental languages, though the differences are also obvious. By means of analyzing progressive marker zai- and -zhe in Chinese and -deiru in Japanese from a cognitive perspective, we find that they share the same or similar cognitive abilities to the world as a result of the same or similar body structures and perspective organs, although this is also leading to the differences.

The mainly differences between the use of progressive markers in these two languages that we have observed are as followings:

- For stative verbs, Chinese progressive marker -zhe can be added to stage-level stative sentences but cannot be used with individual-level verbs while Japanese has few limitations to add the marker -teiru. Furthermore, it could produce pragmatic meanings with the combination of some Japanese stative verbs and aspectual markers.

- For activity verbs, there are more shared features that appear either in the use or in their interpretation.

- For accomplishments verbs, Japanese progressive markers -teiru can have two different interpretations 
in particular contexts. They can be understood as 'original progressive' and also resultative.

- For achievements verbs, the incompatibility of Chinese progressive markers cannot be interpreted as the same 'film-strip' as in English while in Japanese, the resultative interpretation seems to be more prototypical.

Limited corpus in the present study may lead to overgeneralized results. Since linguistic aspect is a universal phenomenon in various languages that has aroused great interest world widely, a more detailed comparative study on the basis of a relatively large corpus seems to be plausible.

\section{ACKNOWLEDGMENT}

We would like to give our sincere gratitude to the teachers and students who provide inspiration, passion and all things that we need to do research, of both the Department of College English and the Department of Japanese Philology of the University of Jinan.

\section{REFERENCES}

[1] C. S. Smith, The parameter of aspect (2nd Edition). Dordrecht, The Netherlands: Kluwer Academic Publishers, 1997.

[2] F. Vlach, "The semantics of the Progressive," In: Tedeschi, P.J. and Zaenen, A.E. (Eds.), Syntax and Semantics, vol.15: Tense and Aspect, New york, Academic Press, 1981, 271-292.

[3] H. Kindaichi, "Kokugo dooshi no ichibunrui [A classification of Japanese verbs]," In H. Kindaichi, 1947, 5-26.

[4] H. Kindaichi, "Tense and aspects of Japanese verbs," In H. Kindaichi, 1954, 27-61.

[5] J. Lyons, Semantics. London, New York \& Melbourne: Cambridge University Press, 1977.

[6] J. Tai, "Verbs and times in Chinese: Vendler's four categories," In Parasession on lexical semantics. Chicago: Chicago Linguistic Society, 1984.

[7] L. Liu and W. X. Zhao, "Un estudio funcionalista del sistema de transitividad tipológica en las lenguas occidentales y orientales: los procesos relacionales con el verbo be en inglés, español, chino y japonés en Harry Potter I," In Actas del VIII congreso internacional de la Asociación Asiática de Hispanistas, Shanghai Foreign Language Education Press, 2015, 152-163.

[8] R. Quirk et al, A comprehensive grammar of the English language. London: Longman, 1985.

[9] R. W. Langacker, "Nouns and Verbs". Language, 1987, 63: 53-94.

[10] R. W. Langacker, Grammar and Conceptualization. Berlin and New York: Mouton de Gruyter, 1991.

[11] R. W. Langacker, "Foundatons of Cognitive Grammar", In Vol. II: Descriptive applications. Standford CA: Standford University Press, 1991.

[12] Y. Okuda, On the study of Japanese Aspect. Tokyo. Japanese Education, 1979.

[13] Z. Vendler, Linguistics in Philosophy. Ithaca: Cornell University Press, 1967. 